\title{
Targeting WISP1 to sensitize esophageal squamous cell carcinoma to irradiation
}

\author{
Hongfang Zhang ${ }^{1, *}$ Honglei Luo ${ }^{2, *}$, Zhaoyang Hu ${ }^{1, *}$, Jin Peng ${ }^{2}$, Zhenzhen Jiang ${ }^{1}$, Tao \\ Song ${ }^{1}$, Bo Wu ${ }^{1}$, Jing Yue ${ }^{1}$, Rongjing Zhou ${ }^{3}$, Ruifei Xie ${ }^{1,4}$, Tian Chen ${ }^{1}$ and Shixiu Wu ${ }^{1}$ \\ ${ }^{1}$ Hangzhou Cancer Institution, Hangzhou Cancer Hospital, Hangzhou, China \\ 2 Department of Radiotherapy, Huai'an First People's Hospital, Huai'an, China \\ ${ }^{3}$ Department of Pathology, Hangzhou Cancer Hospital, Hangzhou, China \\ ${ }^{4}$ Department of Bio-Informatics, Hangzhou Cancer Hospital, Hangzhou, China \\ * These authors contributed equally to this work \\ Correspondence to: Shixiu Wu, email: wushixiu2014@163.com \\ Keywords: ESCC, radioresistance, WISP1, prognostic significance, mechanisms \\ Received: October 21, $2014 \quad$ Accepted: January 13, $2015 \quad$ Published: January 31, 2015
}

This is an open-access article distributed under the terms of the Creative Commons Attribution License, which permits unrestricted use, distribution, and reproduction in any medium, provided the original author and source are credited.

\section{ABSTRACT}

Radiotherapy is a primary treatment modality for esophageal squamous cell carcinoma (ESCC). However, most of patients benefited little from radiotherapy due to refractory radioresistance. We found that WISP1, a downstream target gene of Wnt/ $\beta$-catenin pathway, was re-expressed in $67.3 \%$ of ESCC patients as an oncofetal gene. Expression of WISP1 predicted prognosis of ESCC patients treated with radiotherapy. Overall survival in WISP1-positive patients was significantly poorer than in WISP1-negative patients. Serum concentration of WISP1 after radiotherapy reversely correlated with relapse-free survival. Gain and loss of function studies confirmed that WISP1 mediated radioresistance both in esophageal squamous cancer cells and in xenograft tumor models. Further studies revealed that WISP1 contributed to radioresistance primarily by repressing irradiation-induced DNA damage and activating PI3K kinase. LnCRNA BOKAS was up-regulated following radiation and promoted WISP1 expression and resultant radioresistance. Furthermore, WISP1 facilitated its own expression in response to radiation, creating a positive feedback loop and increased radioresistance. Our study revealed WISP1 as a potential target to overcome radioresistance in ESCC.

\section{INTRODUCTION}

Esophageal carcinoma is the sixth leading cause of cancer-related death and eighth in incidence worldwide [1]. Esophageal squamous cell carcinoma (ESCC), one main pathological subtype of esophageal carcinoma, prevails in Asia and South America. Radiotherapy is recommended as a primary treatment modality for ESCC. However, the prognosis is dismal with less than $20 \%$ of 5 -year survival because of tumor recurrence or metastasis which is primarily mediated by residual therapy-resistant cells $[2,3]$. Tumor radioresistance is very complex and heterogeneous. Several lines of evidences have suggested that gene mutation or aberrant activation of critical signaling pathways within irradiated tumor cells contributed to radioresistance by enhancement of DNA damage repair response [4-6]. Wnt/ $\beta$-catenin pathway plays driving roles in cell growth, differentiation and survival. When aberrantly activated, Wnt/ $\beta$-catenin pathway was demonstrated to mediate radioresistance in glioblastoma, breast cancer and head and neck cancer [7-9]. However, direct blockage of $\mathrm{Wnt} / \beta$-catenin pathway to overcome tumor radioresistance may cause some side effects on normal physiological processes outside the tumor. A mouse experiment has shown that a single injection of Wnt signaling inhibitor DKK1 led to proliferation inhibition of small intestine and colon, and subsequent architectural degeneration and death of most of mice [9]. Thus, special inhibition of Wnt signaling pathway may better control tumor progression and 
simultaneously exert less side effect on normal tissues.

WISP1 was identified as a Wnt1 and $\beta$-catenin responsive gene in 1998 through subtractive hybridization of mouse mammary epithelial cell line C57MG and Wnt1-expressing C57MG cells [10]. It was mainly expressed during embryonic development and was seldom expressed in adult normal tissues. However, WISP1 was reported to be re-expressed under devastating diseased conditions such as cancer or fibrosis [11]. Forced expression of WISP1 in normal rat kidney fibroblast cells led to accelerated cell proliferation, morphological transformation and in vivo tumorigenesis [12]. Furthermore, WISP1 was demonstrated to inhibit programmed cell death by up-regulation of Bcl-xl expression and inhibition of cytochrome $\mathrm{c}$ release [13]. In ESCC, WISP1 was discovered to be highly expressed in cancer tissues compared with in adjacent benign tissues, and its expression had an inverse correlation with the prognosis of patients [14]. However, the exact roles of WISP1 in ESCC progression were poorly elucidated. In our study, we found WISP1-positive ESCC patients had significantly poorer prognosis than those WISP1-negative patients after radiotherapy. Furthermore, serum concentration of WISP1 after radiotherapy was significantly reversely associated with relapse-free survival. Gain and loss of function studies confirmed that WISP1 mediated radioresistance both in ESCC cells and in xenograft tumor models. Furthermore, WISP1 was discovered to mediate radioresistance primarily by repression of irradiationinduced DNA damage and activation of PI3K kinase. The positive feedback loop of WISP1 expression in response to radiation also enhanced radioresistance. In conclusion, our data highlighted WISP1 as a highly attractive target to radiosensitize ESCC.

\section{RESULTS}

\section{WISP1 as an oncofetal gene predicted poor prognosis of ESCC patients after surgery}

By bio-informatics analysis of GEO datasets in PUBMED database, $\mathrm{Wnt} / \beta$-catenin pathway that controls cell fate via multiple mechanisms was found to be constitutively activated in esophageal carcinoma tissues compared with in adjacent normal tissues (Supplementary Fig. S1). Furthermore, we found WISP1, a downstream target gene of Wnt/ $\beta$-catenin pathway, was significantly highly expressed in ESCC tissues compared with in adjacent normal tissues $(P=0.037$ in GSE17351; $P=0.029$ in GSE26886) (Fig. 1A). To uncover the exact expression pattern of WISP1 in ESCC, we compared its level of protein expression in 22-weeks fetal esophagus, normal adult esophagus, ESCC tissues and matched non-neoplastic tissues by immunohistochemical analysis
(IHC). We found WISP1 was highly expressed in fetal esophagus and silenced in normal adult esophagus, but it was re-expressed in 159 primary ESCC patients with 67.3 $\%$ of positive ratio compared with $7.6 \%$ of positive ratio in matched non-neoplastic tissues $(P=0.0042)$, suggesting that WISP1 is an oncofetal gene in ESCC (Fig. 1B and Supplementary Fig. S2A). Furthermore, IHC analysis of tissue chips consisting of other 50 ESCC specimens also confirmed that WISP1-positive ratio in cancer tissues was significantly higher than in matched non-neoplastic tissues (65.8 \% vs $13.4 \%, P=0.004$ ) (Supplementary Fig. S2B and S2C). Survival analyses showed that WISP1-positve ESCC patients $(\mathrm{n}=107)$ had significantly poorer prognosis than those WISP1-negative patients $(\mathrm{n}=52)$ after surgery (Fig. 1C). This finding was also supported by the study by Hideo Baba et al where WISP1 was discovered as a marker of poor prognosis of ESCC patients after surgery [14].

\section{WISP1 predicted poor prognosis of ESCC patients treated with radiotherapy}

Since WISP1 was defined as an oncofetal gene in ESCC, we investigated whether it was involved in tumor radioresponse. By IHC analysis of 12 cancer biopsy specimens, the intensity of WISP 1 expression after 60 Gy of radiation in 30 fractions was found to increase to score of 2.4167 from score of 2.0833 before radiotherapy $(p=0.0394)$ (Fig. 2A and 2B). Furthermore, the WISP1positive ratio also increased to $85.83 \%$ after 60 Gy of radiation in 30 fractions in comparison with $42.92 \%$ before radiotherapy ( $P=0.0026)$ (Fig. $2 \mathrm{~A}$ and $2 \mathrm{~B}$ ). These results indicated that WISP1 expression was significantly up-regulated after multiple fractionated radiation, and those WISP1-positive cells may be more radioresistant than those WISP1-negative cells. To confirm our hypothesis, we investigated whether WISP1 expression was associated with overall survival of ESCC patients treated with radiotherapy. Survival analysis showed that WISP1-positive patients after radiotherapy $(n=52)$ had significantly poorer prognosis than those WISP1-negative patients $(\mathrm{n}=38)$ (Fig. 2C). By ELISA assay, serum concentration of WISP1 was also detected in 27 ESCC patients before radiotherapy and after $40 \mathrm{~Gy}$ of radiation in 20 fractions. Although serum concentration of WISP1 before radiotherapy showed no significant difference between patients with or without tumor relapse (data not shown), significant elevation of WISP1 concentration was detected in relapsed patients $(\mathrm{n}=12)$ than in patients without relapse ( $\mathrm{n}=15)(P=0.041)$ (Fig. 2D). Furthermore, serum WISP1 concentration after radiotherapy was found to significantly correlate with relapse-free survival of ESCC patients ( $\mathrm{p}=0.029)$ (Fig. 2E and Supplementary Fig. $\mathrm{S} 2 \mathrm{D})$. These results revealed WISP1 as a marker of poor prognosis of ESCC patients treated with radiotherapy. 
The clinicopathological characteristics of each cohort of patients analyzed above were summarized in Supplemental Information.

\section{WISP1 mediated radioresistance in ESCC cells}

In our previous study, we had successfully established a radioresistant esophageal squamous cancer cell line KYSE-150R from its parental cell line KYSE150 by multiple fractionated radiation [15]. In view of WISP1 as a marker of poor prognosis of ESCC patients treated with radiotherapy, we investigated whether its expression was up-regulated in radioresistant KYSE-150R cells. We found WISP1 expression in KYSE-150R cells was significantly up-regulated at both mRNA and protein levels compared with in KYSE-150 cells (Fig. 3A and Fig. 3B). When down-regulating WISP1 expression by treatment with $4 \mu \mathrm{g} / \mathrm{mL}$ of WISP1-specific antibody $24 \mathrm{~h}$ before radiation, the radioresistance of KYSE-150R cells was significantly reversed, suggesting that WISP1 may exert functional contribution to the radioresistance (Fig. 3B and Fig. 4A). Up-regulation of WISP1 expression by exposure to $2 \mu \mathrm{g} / \mathrm{mL}$ of recombinant WISP1 protein $24 \mathrm{~h}$ before radiation or stable transduction of WISP1 cDNA conferred KYSE-150 cells significant radioresistance (Fig. 3B and 3C; Fig. 4A and 4B). Furthermore, the radiosensitivity of KYSE-150 cells significantly increased when down-regulating WISP1 expression by stable transduction of WISP1-targeting shRNA (Fig. 3C and 4B). These data revealed that WISP1 was a critical mediator of radioresistance in KYSE-150R cells and KYSE-150 cells. To further confirm the causal relationship of WISP1 and radioresistance, two other esophageal squamous cancer cell lines KYSE-180 and KYSE-30 between

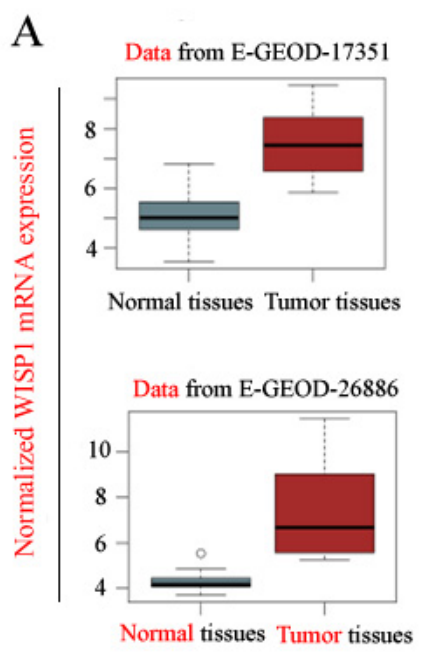

$\mathrm{C}$

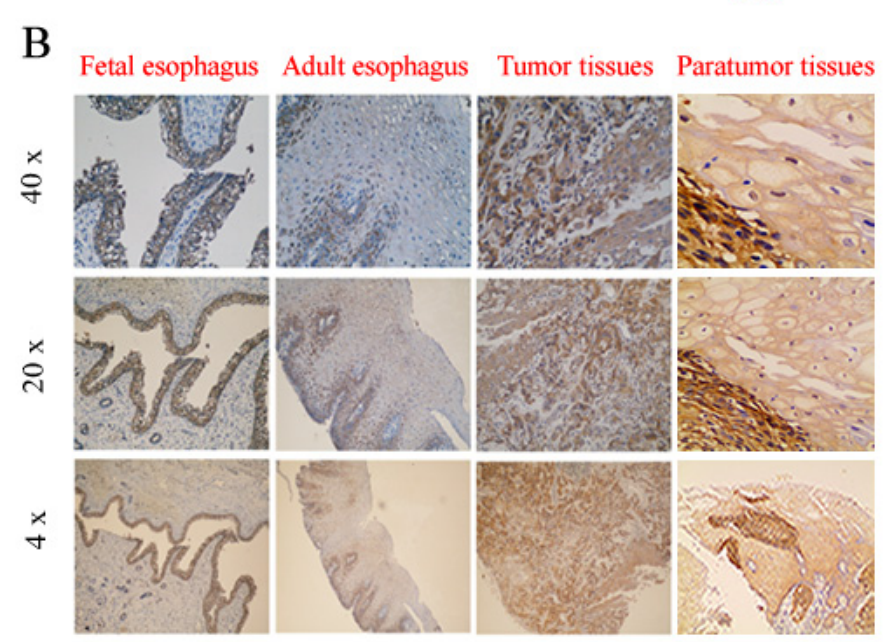

Fig.1: WISP1 as an oncofetal gene was a marker of poor prognosis of ESCC patients after surgery. A. WISP1, a downstream target gene of Wnt/ $\beta$-catenin pathway was highly expressed at mRNA level in ESCC tissues compared with in matched normal tissues by bio-informatics analysis of the data from GSE17351 and GSE26886. B. The expression of WISP1 protein in 22-weeks fetal esophagus, normal adult esophagus, ESCC tissues and matched non-neoplastic tissues by IHC analysis. C. Kaplan-Meier analysis showed that overall survival of WISP1-positive ESCC patients was significantly poorer than those WISP1-negative patients after surgery. The grading of WISP1 expression was described in "Materials and Methods". 
which the level of endogenous WISP1 expression showed great difference have been employed (Fig. 3D). We found KYSE-180 cells with the lowest level of WISP1 expression were most radiosensitive in comparison with KYSE-150 cells and KYSE-30 cells (Fig. 4C). There was no significant difference in the radiosensitivity of KYSE150 cells and KYSE-30 cells between which the level of WISP1 expression was approximately the same (Fig.
4C). Furthermore, we found down-regulation of WISP1 expression by treatment with $4 \mu \mathrm{g} / \mathrm{mL}$ of WISP 1 -specific antibody $24 \mathrm{~h}$ before radiation significantly radiosensitized both KYSE-30 cells and KYSE-180 cells (Fig. 3E and 3F; Fig. 4D and 4E). On the contrary, up-regulation of WISP1 expression by treatment with $2 \mu \mathrm{g} / \mathrm{mL}$ of recombinant WISP1 protein $24 \mathrm{~h}$ before radiation induced both KYSE-30 cells and KYSE-180 cells to display significant
A

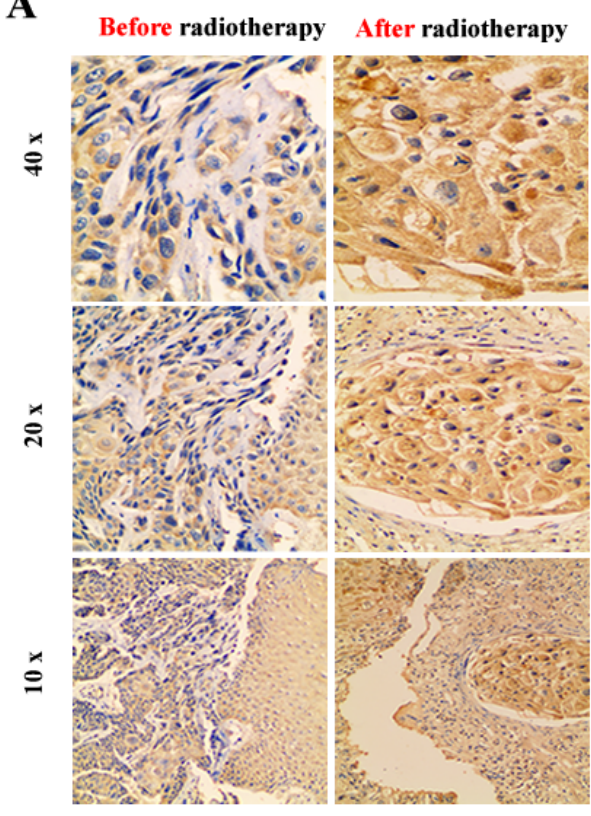

B

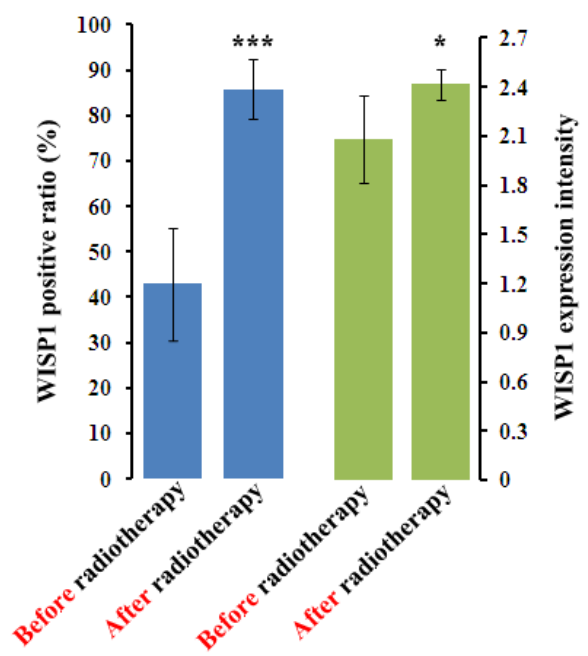

C

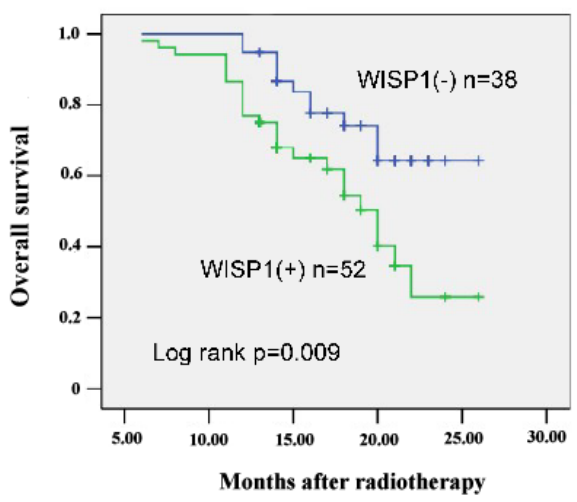

D

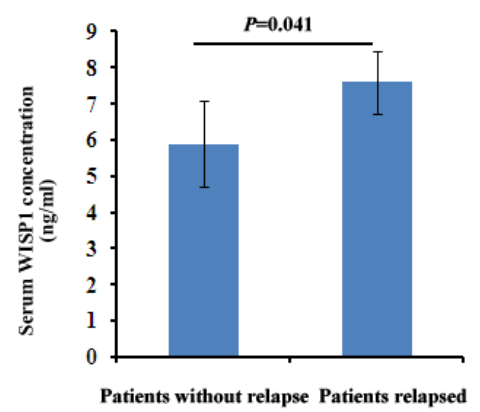

$\mathbf{E}$

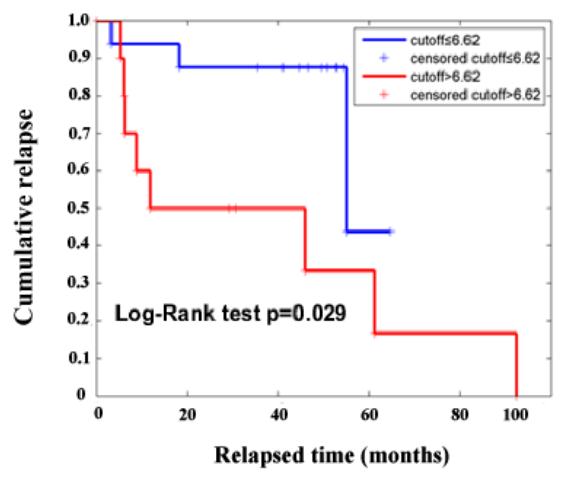

Fig.2: WISP1 was a prognostic factor of ESCC patients treated with radiotherapy. A. A representative result of WISP1 expression in ESCC tissues before radiotherapy and after $60 \mathrm{~Gy}$ of radiation in 30 fractions by IHC analysis. B. Quantitative analysis of the intensity and positive ratio of WISP1 expression in ESCC tissues $(\mathrm{n}=12)$ before radiotherapy and after 60 Gy of radiation in 30 fractions. The grading of WISP1 expression was described in "Materials and Methods". $* * * P<0.005, * P<0.05$, compared with before radiotherapy. C. Kaplan-Meier analysis showed that overall survival of WISP1-positive patients $(n=52)$ after radiotherapy was significantly poorer than those WISP1-negative patients ( $\mathrm{n}=38)$. D. ELISA assay showed that serum concentration of WISP1 after radiotherapy was significantly higher in relapsed ESCC patients $(n=12)$ than in those patients without relapse $(n=15)$. E. Serum concentration of WISP1 after radiotherapy was significantly associated with relapse-free survival of ESCC patients. 
radioresistance (Fig. 3E and 3F; Fig. 4D and 4E). These above results together proved that WISP1 was a key mediator of radioresistance in ESCC cells.

\section{WISP1 mediated radioresistance in xenograft tumor models}

To further confirm the causal relationship of WISP1 and radioresistance in vivo, KYSE-180 xenograft tumors with low level of WISP1 expression had been established in $\mathrm{BALB} / \mathrm{c}$ nude mice. The tumors were treated with fractionated radiation alone or combined with recombinant WISP1 protein. PBS-treated tumors were used as a control. We found fractionated radiation alone (12 Gy in three fractions) significantly inhibited xenograft tumor weight in comparison with PBS treatment
(0.00115 g vs 0.01465 g, $P=0.0027$ ) (Fig. 5A). However, the combination treatment with fractionated radiation and recombinant WISP1 protein (fractionated radiation was performed at day 4,8 and 12 after injection of $2 \mu \mathrm{g} / \mathrm{mL}$ of WISP1 protein had began at day 1 for 12 consecutive days) induced significantly increased tumor weight compared with fractionated radiation alone $(0.00275 \mathrm{~g} v \mathrm{~s}$ $0.00115 \mathrm{~g}, P=0.0298)$. Treatment with WISP1 alone did not have significant promotion effect on tumor weight in comparison with PBS treatment $(0.01465 \mathrm{~g} v s 0.0138$ g, $P=0.0629$ ) (Fig. 5A). These results indicated that upregulation of WISP1 expression in KYSE-180 xenograft tumors significantly enhanced radioresistance.

KYSE-30 xenograft tumors with high level of WISP1 expression had also been developed in BALB/c mice and exposed to indicated treatments. We found

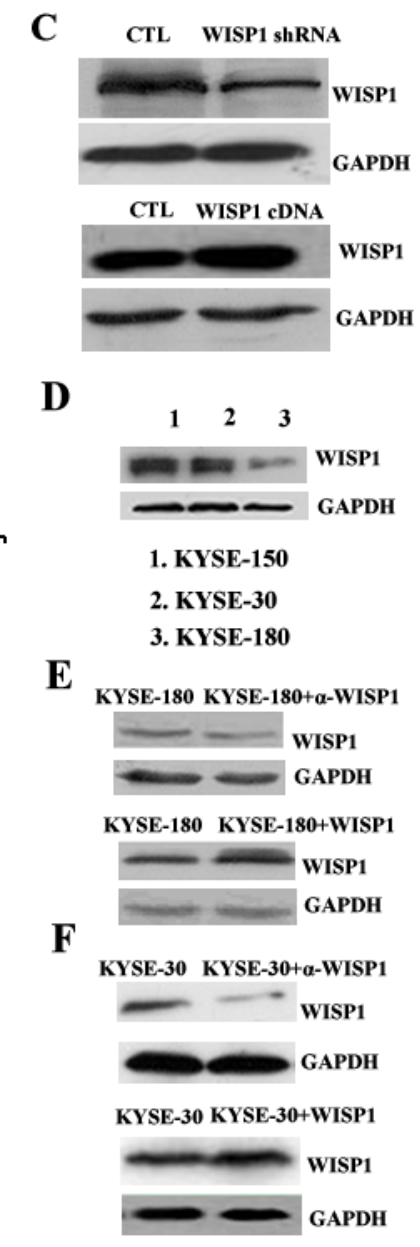

Fig.3: The expression of WISP1 in multiple ESCC cells. A. The relative mRNA level of WISP1 in radioresistant cell KYSE$150 \mathrm{R}$ and in its parental cell KYSE-150 by qRT-PCR analysis. $* * * P<0.005$, compared with KYSE-150 cell. B. Western blotting analysis of WISP1 expression in KYSE-150 cell treated with or without $2 \mu \mathrm{g} / \mathrm{mL}$ of recombinant WISP1 protein for $24 \mathrm{~h}$ and in KYSE-150R cell treated with or without $4 \mu \mathrm{g} / \mathrm{mL}$ of anti-WISP1 antibody $\alpha$-WISP1 for $24 \mathrm{~h}$. C. Western blotting analysis of WISP1 expression in KYSE-150 cell transduced with lentivirus vector carrying WISP1-targeting shRNA or WISP1 cDNA. D. Western blotting analysis of WISP1 expression in ESCC cells KYSE-150, KYSE-30 and KYSE-180. E. Western blotting analysis of WISP1 expression in KYSE-180 cell treated with or without $4 \mu \mathrm{g} / \mathrm{mL}$ of anti-WISP1 antibody $\alpha$-WISP1 or $2 \mu \mathrm{g} / \mathrm{mL}$ of recombinant WISP1 protein for $24 \mathrm{~h}$. F. Western blotting analysis of WISP1 expression in KYSE-30 cell treated with or without $4 \mu \mathrm{g} / \mathrm{mL}$ of anti-WISP1 antibody $\alpha$-WISP1 or $2 \mu \mathrm{g} / \mathrm{mL}$ of recombinant WISP1 protein for $24 \mathrm{~h}$. GAPDH served as a loading control in all of the western blotting analysis above. 

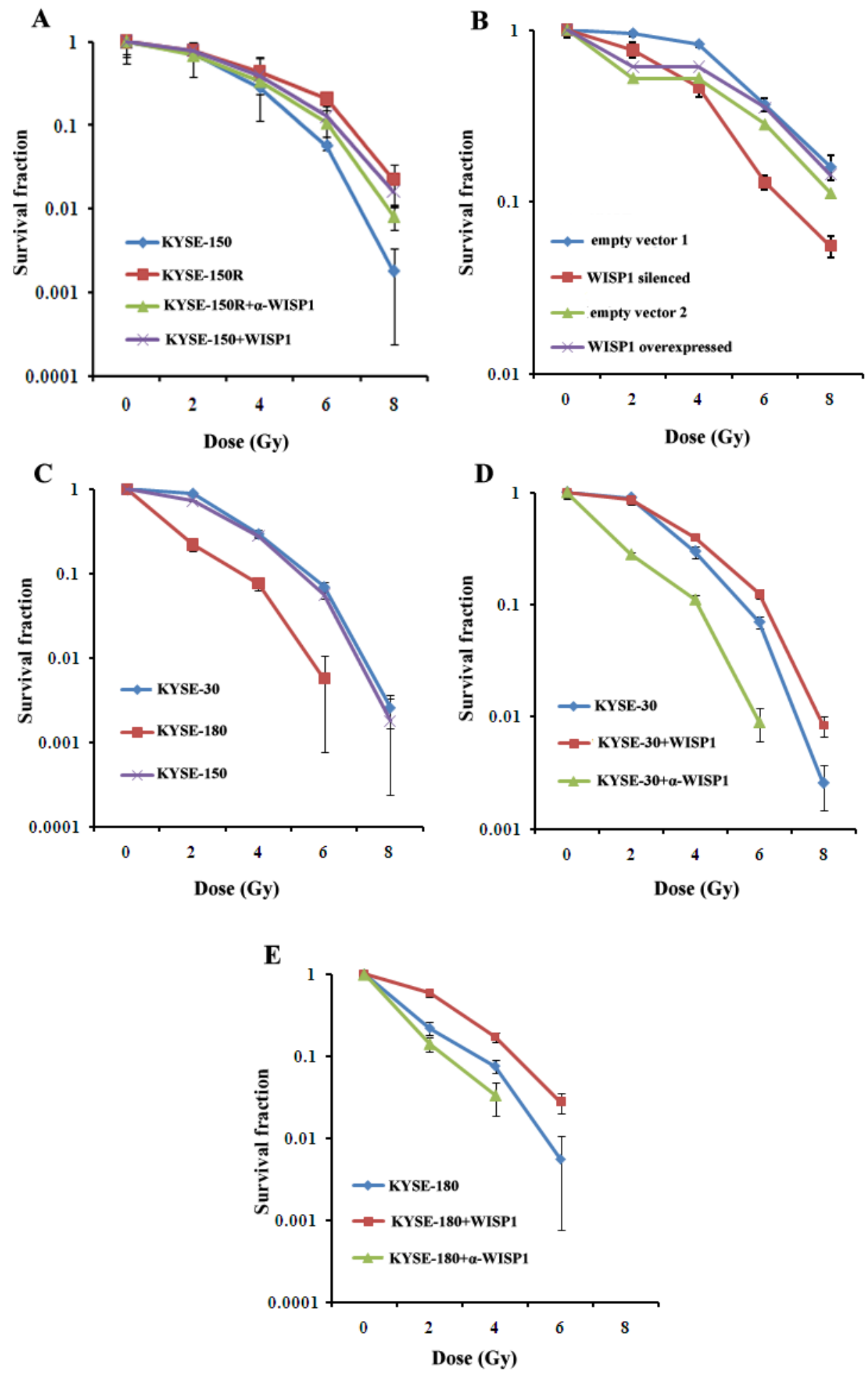

Fig.4: WISP1 mediated radioresistance in ESCC cells. A. The radiosensitivity of KYSE-150R cell with or without treatment with $4 \mu \mathrm{g} / \mathrm{mL}$ of anti-WISP1 antibody $\alpha$-WISP1 $24 \mathrm{~h}$ before radiation, and the radiosensitivity of KYSE-150 cell with or without treatment with $2 \mu \mathrm{g} / \mathrm{mL}$ of recombinant WISP1 protein $24 \mathrm{~h}$ before radiation. B. The radiosensitivity of KYSE-150 cell with WISP1 silenced or overexpressed by stable transduction of WISP1-targeting shRNA or WISP1 cDNA. Empty vector 1 referred to empty lentivirus vector without carrying WISP1-targeting shRNA. Empty vector 2 referred to empty lentivirus vector without carrying WISP1 cDNA. C. The radiosensitivity of KYSE-30, KYSE-180 and KYSE-150 cells. D. The radiosensitivity of KYSE-30 cell treated with or without $4 \mu \mathrm{g} / \mathrm{mL}$ of anti-WISP1 antibody $\alpha$-WISP 1 or $2 \mu \mathrm{g} / \mathrm{mL}$ of recombinant WISP1 protein $24 \mathrm{~h}$ before radiation. E. The radiosensitivity of KYSE-180 cell with or without treatment with $4 \mu \mathrm{g} / \mathrm{mL}$ of anti-WISP1 antibody $\alpha$-WISP1 or $2 \mu \mathrm{g} / \mathrm{mL}$ of recombinant WISP1 protein $24 \mathrm{~h}$ before radiation. The radiosensitivity of the above cells was detected at $0 \mathrm{~Gy}, 2 \mathrm{~Gy}, 4 \mathrm{~Gy}, 6 \mathrm{~Gy}$ and $8 \mathrm{~Gy}$ of radiation by clonogenic survival assay. 
A

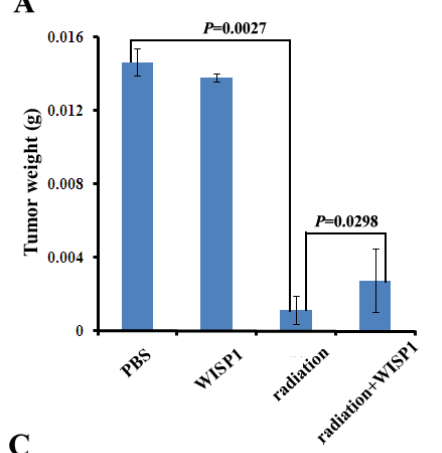

C

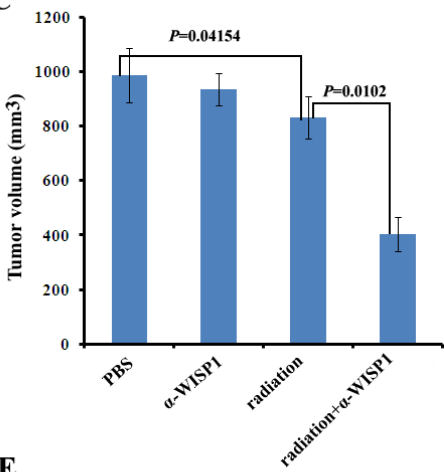

$\mathbf{E}$

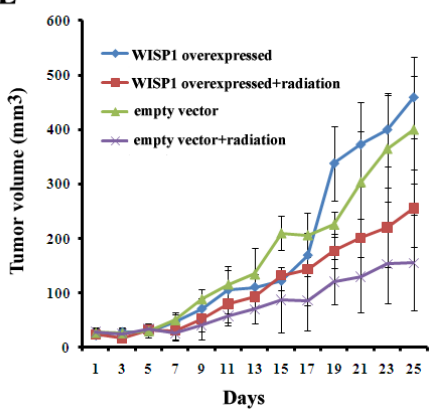

B

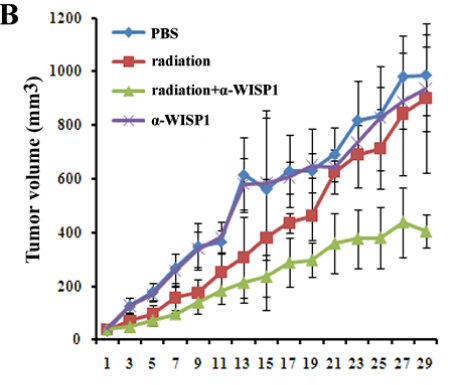

Days

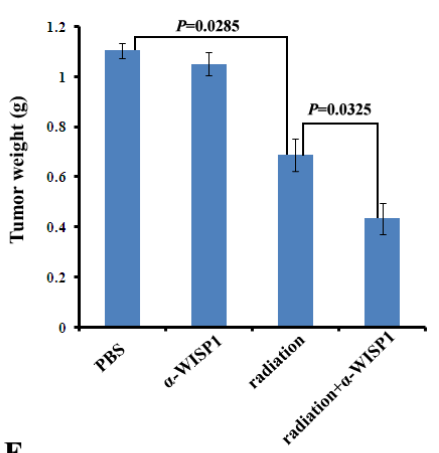

F

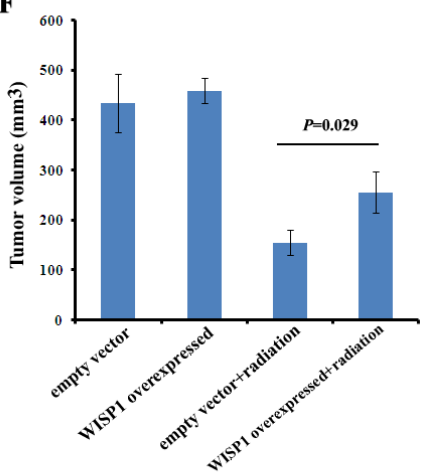

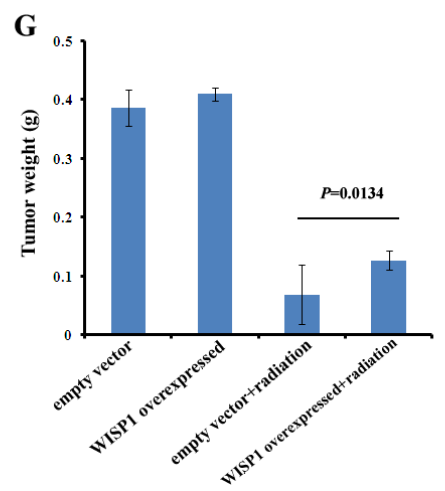

Fig.5: WISP1 mediated radioresistance in xenograft tumor models. A. The weight of KYSE-180 xenograft tumors after treatment with PBS, fractionated radiation alone (12 Gy in three fractions every four days), recombinant WISP1 protein alone (2 $\mu \mathrm{g} / \mathrm{mL}$ daily for 12 consecutive days) or fractionated radiation combined with recombinant WISP1 protein (fractionated radiation was performed at day 4,8 and 12 after injection of $2 \mu \mathrm{g} / \mathrm{mL}$ of WISP 1 protein had began at day 1 for 12 consecutive days). The weight of tumors was measured 10 days after the end of treatment. B. The growth curves of KYSE-30 xenograft tumors receiving different treatments including PBS, fractionated radiation alone (12 Gy in three fractions every four days), anti-WISP1 antibody $\alpha$-WISP1 (4 $\mu \mathrm{g} / \mathrm{mL}$ daily for 12 consecutive days) alone and fractionated radiation combined with $\alpha$-WISP1 (fractionated radiation was performed at day 4, 8 and 12 after injection of $4 \mu \mathrm{g} / \mathrm{mL}$ of $\alpha$-WISP1 had began at day 1 for 12 consecutive days). Tumor volume was calculated as described in "Materials and Methods". C. The volume of xenograft tumors in "B" on day 29. D. The weight of xenograft tumors in "B" on day 29. E. The growth curve of KYSE-150 xenograft tumors transduced with empty vector or WISP1 cDNA after treatment with or without 12 Gy of radiation in three fractions every four days. Tumor volume was calculated as described in "Materials and Methods". F. The volume of tumors in "E" on day 25. G. The weight of tumors in "E" on day 25. 
fractionated radiation alone (12 Gy in three fractions) significantly inhibited tumor volume and weight compared with PBS treatment $\left(830.8727 \mathrm{~mm}^{3}\right.$ vs $987.9588 \mathrm{~mm}^{3}$, $P=0.04154 ; 0.6882$ g vs 1.1038 g, $P=0.0285$ ) (Fig. 5B, $5 \mathrm{C}$ and 5D). Moreover, the tumor growth inhibitory effect of fractionated radiation was further significantly enhanced when combined with anti-WISP1 antibody (fractionated radiation was performed at day 4, 8 and 12 after injection of $4 \mu \mathrm{g} / \mathrm{mL}$ of anti-WISP1 antibody had began at day 1 for 12 consecutive days) (409.9544 $\mathrm{mm}^{3}$ vs $830.8727 \mathrm{~mm}^{3}, P=0.0102 ; 0.4348 \mathrm{~g}$ vs $0.6882 \mathrm{~g}$, $P=0.0325)$. Treatment with anti-WISP1 antibody alone had no significant inhibitory effect on tumor growth (934.9269 $\mathrm{mm}^{3}$ vs $987.9588 \mathrm{~mm}^{3}, P=0.1153 ; 1.0508 \mathrm{~g} v \mathrm{~s}$ $1.1038 \mathrm{~g}, P=0.3153$ ) (Fig. 5B, 5C and 5D). These results indicated that down-regulation of WISP1 expression could significantly radiosensitize KYSE-30 xenograft tumors.

Furthermore, we also investigated whether upregulation of WISP1 expression by stable transduction of WISP1 cDNA in lentivirus vector could reduce the radiosensitivity of KYSE-150 xenograft tumors. The tumors transduced with empty vector were used as a control. We found WISP1-overexpressed tumors were more radioresistant with significantly increased tumor volume and weight than control tumors when treated with 12 Gy of radiation in three fractions $(255.3928$ $\mathrm{mm}^{3}$ vs $154.9216 \mathrm{~mm}^{3}, P=0.029 ; 0.12705 \mathrm{~g} v s 0.0687 \mathrm{~g}$, $P=0.0134$ ) (Fig. 5E, 5F and 5G). Up-regulation of WISP1 expression alone had no significant promotion effect on the volume of KYSE-150 xenograft tumors (459.1966 $\mathrm{mm}^{3}$ vs $434.0424 \mathrm{~mm}^{3}, P=0.0797 ; 0.4098 \mathrm{~g}$ vs $0.3862 \mathrm{~g}$, $P=0.1315$ ) (Fig. 5E, 5F and 5G). In general, these data with three xenograft tumors together confirmed that WISP1 mediated radioresistance of ESCC in vivo as it did in vitro.

\section{WISP1 repressed $\gamma-\mathrm{H} 2 \mathrm{AX}$ expression and activated PI3K kinase}

WISP1 was demonstrated to inhibit cell apoptosis following DNA damage through inhibition of cytochrome c release and up-regulation of Bcl-xl expression [13]. In our context, to clarify the mechanisms by which WISP1 mediated radioresistance, the pathways that were enriched in WISP1-overexpressed esophageal cancer tissues were systemically analyzed by use of bioinformatics tool GSEA. We found the top four enriched pathways were about immune response, response to wound, defense response and response to external stimulus (Fig. 6A). Particularly, there were 185 genes involved in tumor response to wound, and 299 genes in tumor response to external stimulus (Fig. 6A, 6B and 6C), suggesting that WISP1 may be closely related to cell defense response to wound. In our context, we investigated whether WISP1 participated in cell response to irradiation-induced double- strand breaks (DSBs) of DNA, one known major wound for irradiated cells. We found the expression level of $\gamma$-H2AX, a marker of DSBs, in WISP1-overexpressed KYSE-150 cells was significantly lower than in control cells $30 \mathrm{~min}$ after 6 Gy of radiation (Fig. 6D and 6E, $P=0.0369$ ). This DNA damage inhibitory effect of WISP1 would greatly reduce irradiation-induced cell death. Furthermore, WISP1-regulated anti-apoptotic pathways in ESCC were also investigated by high content screening of kinases inhibitor library (Supplementary Table S5). We found treatment with $30 \mu \mathrm{M}$ of PI3K kinase inhibitor AS-252424 $4 \mathrm{~h}$ before radiation greatly reversed the inhibitory effect of WISP1 on irradiation-induced $\gamma$-H2AX expression in KYSE-150 cells, while AS-252424 alone had little effect on $\gamma$-H2AX expression (Fig. 6F). This result suggested that WISP1 mediated radioresistance of ESCC possibly through activation of anti-apoptotic PI3K kinase. By western blotting analysis, PI3K kinase was found to be obviously activated in WISP1-overexpressed KYSE150 cells. Inhibition of PI3K kinase activity by treatment with $30 \mu \mathrm{M}$ of its inhibitor AS-252424 greatly enhanced cell growth inhibitory effect of radiation on WISP1overexpressed KYSE-150 cells (Supplementary Fig. S3A and Fig. 6G). Moreover, this combination treatment with AS-252424 and radiation obviously promoted $\gamma$-H2AX expression in WISP1-overexpressed KYSE150 cells compared with radiation alone (Supplementary Fig. S3B). These results may together prove that WISP1 mediated radioresistance of ESCC mainly by repression of irradiation-induced DNA damage and activation of antiapoptotic PI3K kinase.

\section{LncRNA BOKAS promoted WISP1 up-regulation and radioresistance}

To further clarify the mechanisms of WISP1mediated radioresistance in ESCC, the expression pattern of WISP1 following radiation was also investigated in KYSE-150 cells. We found the level of WISP1 expression in KYSE- 150 cells peaked $3 \mathrm{~h}$ after 6 Gy of radiation (Fig. $7 \mathrm{~A}$ and $7 \mathrm{~B})$. However, when the transcription process was blocked by treatment with $10 \mu \mathrm{g} / \mathrm{mL}$ of actinomycin $\mathrm{D} 1$ $\mathrm{h}$ before 6 Gy of radiation, the level of WISP1 expression in KYSE-150 cells did not increase (Supplementary Fig. S4 and Fig. 7B). Therefore, we proposed that irradiationinduced WISP1 up-regulation occurred at transcription or post-transcription level. Long non-coding (Lnc) RNAs have recently emerged as important regulators of their target genes expressions at transcription or posttranscription level [18]. In our study, the LncRNA that was associated with irradiation-induced WISP1 up-regulation was explored. We examined the expressions of 94 cancerrelated LncRNAs in LncRNAs \& disease database in WISP1-overexpressed KYSE-150 cells and in control cells before and $30 \mathrm{~min}$ after $6 \mathrm{~Gy}$ of radiation. There 
$\mathbf{A}$

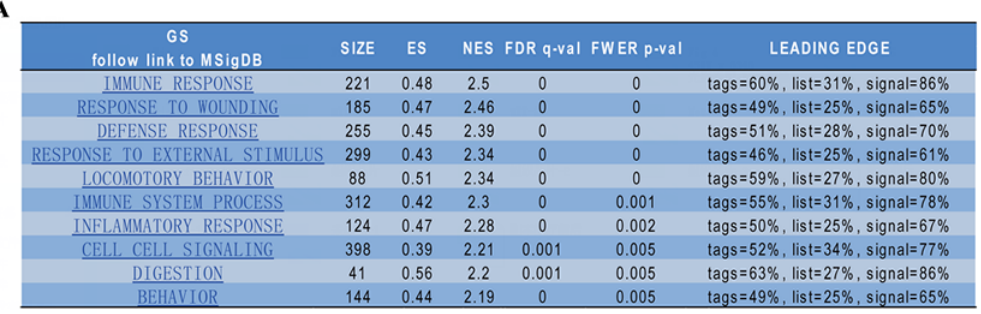

B

C
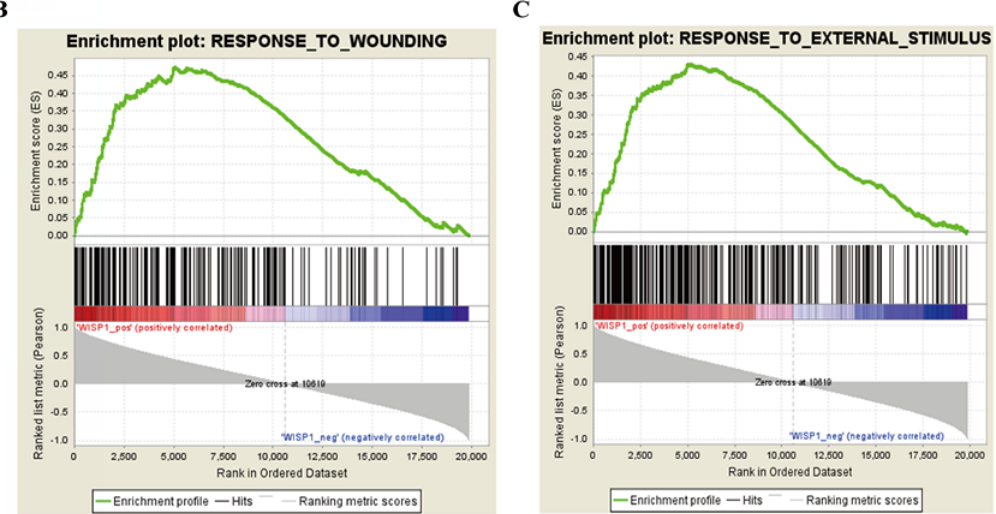

D

CTL

WISP1 overexpressed
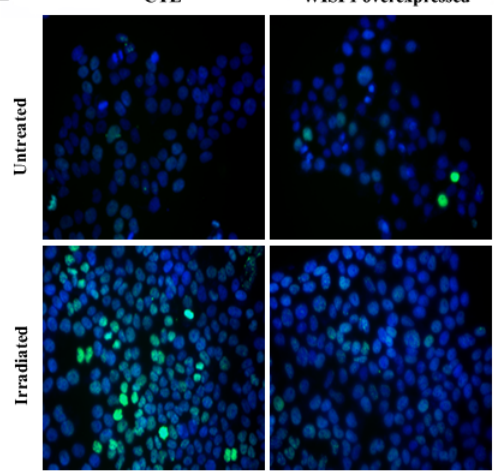

$\mathbf{F}$

$\mathbf{E}$
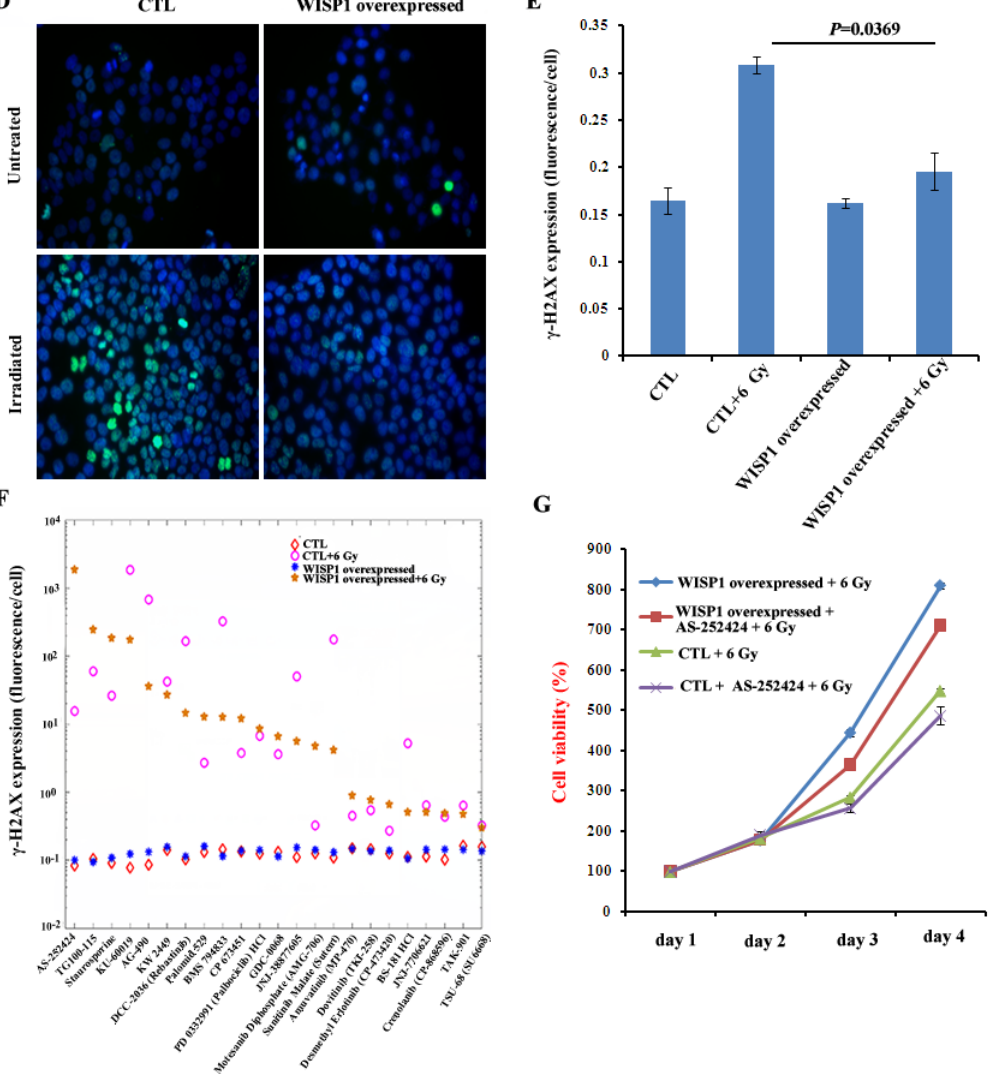

Fig.6: WISP1 inhibited irradiation-induced DNA damage and activated anti-apoptotic PI3K kinase. A. The analysis of enriched pathways in WISP1-overexpressed esophageal cancer tissues by use of bioinformatics tool GSEA. B. The result of GSEA analysis of the relationship between WISP1 and wounding response pathway. C. The result of GSEA analysis of the relationship between WISP1 and cell response to external stimulus. D. Immunofluorescence analysis of $\gamma$-H2AX expression 30 min after 6 Gy of radiation in control KYSE-150 cells transduced with empty vector and in WISP1-overexpressed KYSE-150 cells transduced with WISP1 cDNA. Magnification: $40 \times$. E. Quantitative analysis of $\gamma$-H2AX expression in "D". F. Immunofluorescence analysis of $\gamma-\mathrm{H} 2 \mathrm{AX}$ expression 30 min after 6 Gy of radiation in empty vector-transduced control KYSE-150 cells and in WISP1-overexpressed KYSE-150 cells with or without pretreatment with $30 \mu \mathrm{M}$ of indicated kinase inhibitors $4 \mathrm{~h}$ before radiation. G. Detection of the growth of empty vector-transduced control KYSE-150 cells and WISP1-overexpressed KYSE-150 cells with or without pretreatment with $30 \mu \mathrm{M}$ of PI3K kinase inhibitor AS-252424 4 h before 6 Gy of radiation by MTT assay. 
were 14 LncRNAs up-regulated and 5 LncRNAs downregulated $30 \mathrm{~min}$ after 6 Gy of radiation, all of which showed more than 2-fold change in expression level (Fig. 7C). Interestingly, WISP1 was found to play an opposite effect on radiation regulation of LncRNAs expression (Fig. 7C). Among these LncRNAs, BOKAS was found to be closely related to irradiation-induced WISP1 upregulation. When down-regulating BOKAS expression by transfection with BOKAS-targeting siRNA, the level of WISP1 expression in KYSE-150 cells decreased in a siRNA dose-dependent manner (Supplementary Fig. S5). We found the level of WISP1 expression in KYSE150 cells decreased from $351.09 \mathrm{pg} / \mathrm{ml}$ to $99.3578 \mathrm{pg} / \mathrm{ml}$ when transfecting $100 \mathrm{nM}$ of BOKAS-targeting siRNA $(P=0.0242)$ (Fig. 7D). Furthermore, the level of WISP1 expression in BOKAS siRNA-transfected KYSE-150 cells was only slightly up-regulated from $99.3578 \mathrm{pg} / \mathrm{ml}$ to $116.14 \mathrm{pg} / \mathrm{ml} 30 \mathrm{~min}$ after 6 Gy of radiation (Fig. 7D, $P=0.2791$ ). In comparison, the level of WISP1 expression in empty vector-transfected KYSE-150 cells increased from $351.09 \mathrm{pg} / \mathrm{ml}$ to $569.93 \mathrm{pg} / \mathrm{ml} 30 \mathrm{~min}$ after 6 Gy of radiation (Fig. 7D, $\mathrm{P}=0.0136$ ). When WISP1 up-regulation was attenuated by transfection with $100 \mathrm{nM}$ of BOKAStargeting siRNA, irradiation-induced DNA damage was greatly enhanced in KYSE-150 cells (Fig. 7E). These results indicated that BOKAS promoted WISP1 upregulation and resultant radioresistance.

WISP1 was reported to induce its own expression in adult mouse cardiomyocytes by phosphorylation and inactivation of GSK3 $\beta$, a key enzyme that inhibits Wnt/ $\beta$ catenin pathway $[19,20]$. In our study, we investigated whether WISP1 could also induce its own expression in KYSE-150 cells. By treatment with $2 \mu \mathrm{g} / \mathrm{mL}$ of recombinant WISP1 protein for $24 \mathrm{~h}$, the expressions of $\beta$-catenin and WISP1 in KYSE-150 cells both increased as a result of increased phosphorylation and degradation of GSK3 $\beta$ (Fig. 7B). This positive feedback loop of WISP1 expression may further enhance refractory radioresistance of ESCC.

\section{DISCUSSION}

Radiotherapy is often used for the treatment of ESCC patients. However, the prognosis is very poor [2, 3]. The mechanisms of radioresistance are known to alter in different cell types and even in different subpopulations within the tumor [21-24]. Although there have been several studies performed to explore the radiosensitizing targets, it still remained a tough problem to overcome ESCC radioresistance [25-32]. Our study revealed WISP1 as an excellent predictor of radiotherapy outcomes and also as a potential target to reverse ESCC radioresistance. Due to great difference of WISP1 expression in esophageal carcinoma tissues and in adjacent normal tissues, targeting WISP1 to reverse radioresistance would be more tumorspecific and thereby have minor adverse effect on normal tissues. Furthermore, WISP1 allocated to the CCN family that contains six members with highly conserved structure is a secreted matricellular protein, which may facilitate the development of antibody-based radiosensitizing therapies in ESCC [33]. All of these advantages of WISP1 may accelerate establishment of personalized radiotherapeutic regimens from which patients would acquire more therapeutic benefits.

Several lines of evidence have demonstrated that DNA damage response was closely associated with cell radiosensitivity [34-38]. DNA double-strand breaks (DSBs) is recognized as the main form of DNA damage induced by radiation [39]. $\gamma-\mathrm{H} 2 \mathrm{AX}$, a known marker of DSBs, is highly expressed following radiation and plays vital roles in initiating DNA damage response by interaction with the MRE11-RAD50-NBS1 (MRN) complex, which activates the ataxia telangiectasia mutated (ATM) kinase and/or ataxia telangiectasia and Rad3related (ATR) kinase [40]. When activated, these two kinases phosphorylate their downstream genes such as BRCA1, p53, Chk1 and Chk2 to induce cell cycle arrest and/or cell apoptosis. In our study, WISP1 was found to inhibit irradiation-induced $\gamma-\mathrm{H} 2 \mathrm{AX}$ expression, leading to greatly attenuated DNA damage response and reduced inhibitory effect of radiation on ESCC. Bio-informatics analysis also proved that WISP1 was closely related to cell defense response to external stimulus. Furthermore, WISP1 was found to mediate radioresistance by activation of anti-apoptotic PI3K kinase. It has been reported that PI3K kinase was associated with three known major radioresistance mechanisms including intrinsic radioresistance, tumor cell proliferation and hypoxia [4]. Inhibition of PI3K kinase activity could enhance tumor radiosensitivity [41-43]. Our study revealed that PI3K kinase was a downstream effector of WISP1 in the development of ESCC radioresistance. Although WISP1 mediated radioresistance of ESCC, it was reported to play positive roles in lung cancer by inhibition of cell motility and invasion [44]. In other human cancers such as endometrial endometrioid adenocarcinoma, breast cancer and colorectal cancer, the expression of WISP1 was also associated with poor prognosis of patients [4547]. Thus, WISP1 regulated cancer progression in a cell type-dependent manner and may play contradictory roles among different cancers.

The expression of WISP1 during embryonic development and in adult normal tissues is exquisitely controlled by a complicated regulatory machinery. When deregulated, aberrant expression of WISP1 often led to accelerated cell growth and enhanced motility and invasion [48-50]. However, the mechanisms that caused WISP1 expression disordered have remained mostly unknown. In our study, we found WISP1 was significantly up-regulated following radiation at transcription or posttranscription level. LncRNAs are emerging regulators of their target genes expressions at transcription or post- 

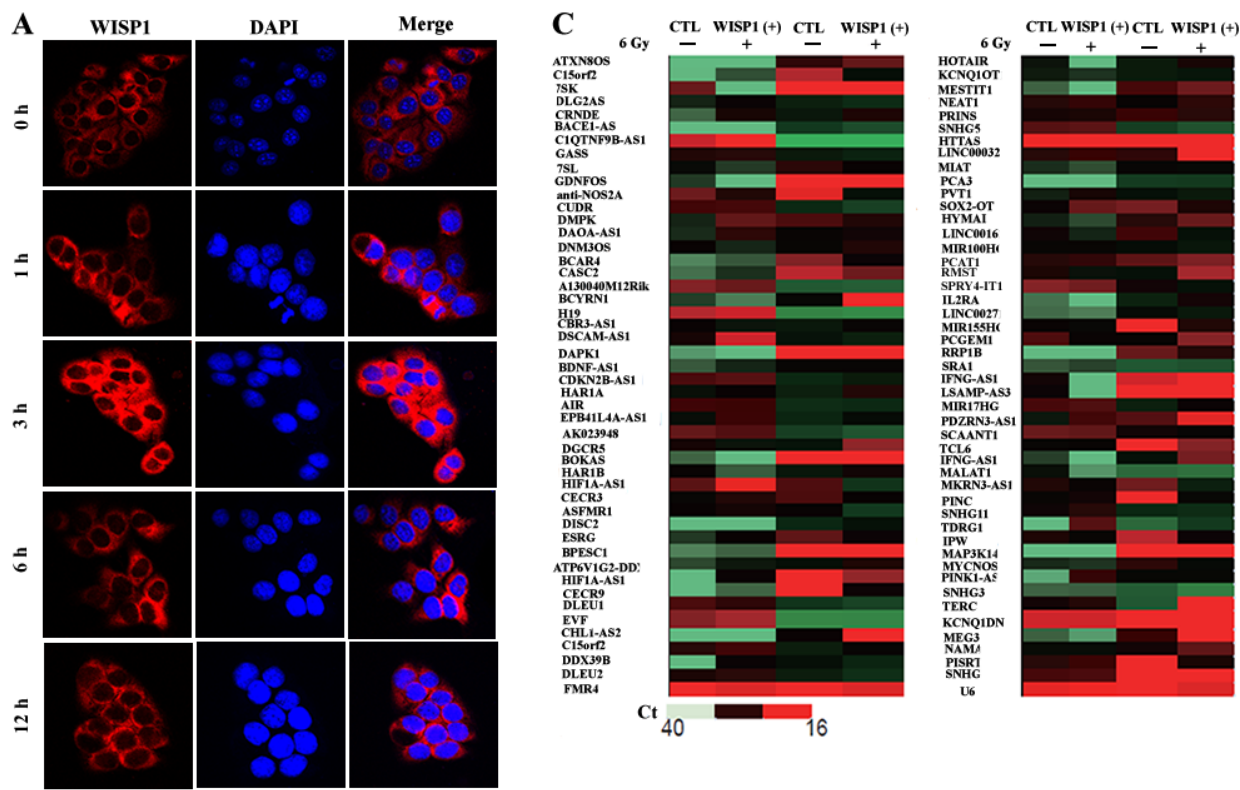

B
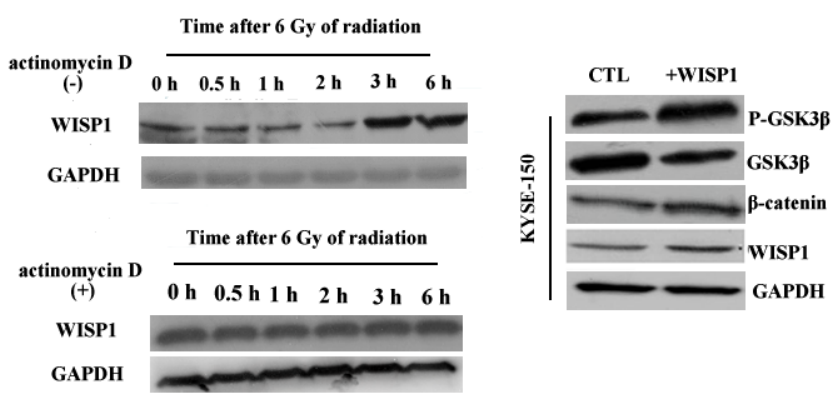

D

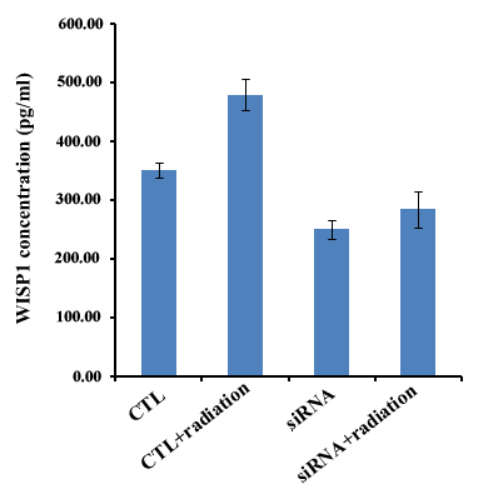

$\mathbf{E}$

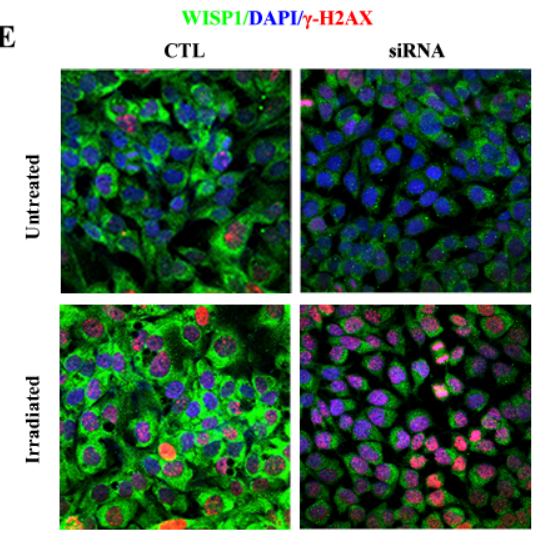

Fig.7: LncRNA BOKAS promoted WISP1 up-regulation and radioresistance. A. The expression of WISP1 protein in KYSE150 cells after 6 Gy of radiation by immunofluorescence analysis. B. Western blotting analysis of WISP1 expression in KYSE-150 cells treated with or without $10 \mu \mathrm{g} / \mathrm{mL}$ of actinomycin D $1 \mathrm{~h}$ before $6 \mathrm{~Gy}$ of radiation and the expressions of P-GSK3 $\beta$, GSK3 $\beta, \beta$-catenin and WISP1 in KYSE-150 cells treated with or without $2 \mu \mathrm{g} / \mathrm{mL}$ of recombinant WISP1 protein for $24 \mathrm{~h}$. GAPDH was used as a loading control. C. qRT-PCR analysis of 94 cancer-related LncRNAs in control KYSE-150 cells transduced with empty vector and in WISP1-overexpressed KYSE-150 cells transduced with WISP1 cDNA before radiation and $30 \mathrm{~min}$ after $6 \mathrm{~Gy}$ of radiation. D. Detection of WISP1 concentration in control KYSE-150 cells transfected with empty vector and in KYSE-150 cells transfected with $100 \mathrm{nM}$ of BOKAS-targeting siRNA before radiation and $30 \mathrm{~min}$ after $6 \mathrm{~Gy}$ of radiation by ELISA assay. E. Immunofluorescence analysis of $\gamma$-H2AX expression in control KYSE-150 cells transfected with empty vector and in KYSE-150 cells transfected with $100 \mathrm{nM}$ of BOKAS-targeting siRNA before radiation and 30 min after 6 Gy of radiation. 
transcription level. There were studies demonstrating that LncRNAs have several important biological functions such as cell cycle regulation, chromatin modification and nuclear-cytoplasmic tracking [51-53]. Radiation was reported to induce significant up-regulation or downregulation of LncRNAs [54-57]. However, whether LncRNA regulated WISP1 expression and was involved in cell radioresponse has been less studied. LncRNA BOKAS was discovered as a natural antisense transcript of BOK, a member belonging to the pro-apoptotic Bcl-2 family. BOKAS was reported to be expressed in certain cancer tissues and in testis, but not other normal adult tissues [58]. Overexpression of BOKAS was demonstrated to inhibit Bok-induced apoptosis in HeLa cells. In our study, BOKAS was demonstrated to be up-regulated following radiation and promoted WISP1 expression and resultant radioresistance. However, how BOKAS promoted WISP1 expression needs to be further clarified in the future work.

Furthermore, our study demonstrated that WISP1 promoted phosphorylation and inactivation of GSK3 $\beta$, a key enzyme that inhibits activation of $\mathrm{Wnt} / \beta$-catenin pathway. Less active GSK3 $\beta$ enhanced activation of Wnt/ $\beta$-catenin pathway and resultant WISP1 expression; in turn, increased WISP1 expression further led to phosphorylation and inactivation of GSK3 $\beta$, which eventuated in a strong positive feedback loop of WISP1 expression and concomitant refractory radioresistance. Wnt/ $\beta$-catenin pathway was reported to inhibit GSK3 $\beta$ activity through an unknown mechanism [59]. Here, our study revealed that WISP1, a downstream target gene of Wnt/ $\beta$-catenin pathway, was at least in part responsible for attenuated activity of GSK3 $\beta$. GSK3 $\beta$ is known to be a specific substrate of Akt kinase. When signaling cascade triggered activation of Akt, GSK $3 \beta$ would be phosphorylated and inactivated by the interaction with Akt [59]. Since WISP1 activation of Akt kinase has been reported previously $[13,19]$, we therefore proposed that WISP1 inhibited GSK3 $\beta$ activity possibly through activation of Akt. Together, our data highlighted WISP1 as a promising target to reverse ESCC radioresistance, and it deserves further exploration in preclinical studies.

\section{MATERIALS AND METHODS}

\section{Cell culture and agents}

The human esophageal squamous cancer cell line KYSE-150 was obtained from the Japanese Collection of Research Bioresources (JCRB, Osaka, Japan). The radioresistant esophageal cancer cell line KYSE-150R was established from KYSE-150 by multiple fractionated radiation and had been used in our previous study [15]. The other esophageal squamous cancer cell lines KYSE30 and KYSE-180 were obtained from American Type
Culture Collection. All of esophageal squamous cancer cell lines used in our study were cultured in RPMI-1640 medium (Gibco, Life Technologies Inc., Grand Island, NY, USA) supplemented with $10 \%$ of fetal bovine serum and incubated at $37{ }^{\circ} \mathrm{C}$ in $5 \% \mathrm{CO}_{2} / 95 \%$ air.

Antibodies against $\gamma$-H2AX, p-PI3K (Tyr199/458) and PI3K were purchased from Cell Signaling Technology (Beverly, MA, USA). Anti-WISP1 antibody $\alpha$-WISP1 and recombinant WISP1 protein were purchased from Abcam (Cambridge, MA, USA). Antibodies against phosphoGSK3 $\beta$ (Ser9) and total GSK3 $\beta$ were obtained from Epitomics (Burlingame, CA, USA). Antibody against total GAPDH was purchased from Santa Cruz Biotechnology (Dallas, TX, USA). Actinomycin D was purchased from BangYi Biotechnology Co. (Shanghai, China).

\section{Animals and clinical specimens of ESCC patients}

6-week-old female BALB/c nude mice were purchased from Vital River (Beijing, China) and maintained under standard conditions in Experimental Animal Center in Zhejiang Chinese Medicine University. All of the animal protocols in our study were in accordance with the institutional animal welfare guidelines of Zhejiang Chinese Medicine University.

The surgically resected or biopsy specimens of ESCC tissues and serum samples used in our study were collected with the informed content of patients obtained. Each cohort of patients analyzed provided the following information: age, gender, TNM stage and therapeutic regimens received as shown in Supplemental Information. The tissue chips consisting of various independent groups of 50 primary ESCC specimens and matched non-neoplastic tissues were purchased from Alenabio Biotechnology Co (Xi'an, China).

\section{RNA extraction, qRT-PCR and LncRNA PCR array}

Total RNA was extracted from cancer cells using the Trizol Reagent (Invitrogen life technologies, Carlsbad, CA, USA) following the manufacturer's instructions. Reverse transcription was performed with Fermentas K1622 following the manufacturer's instructions. Quantitative RT-PCR (qRT-PCR) was conducted using SYBR green (Abgene, Epsom, UK) according to the manufacturer's instructions. LncRNA PCR array (Supplementary Table S6) (Funeng biology Co, Shanghai, China) containing 94 cancer-related LncRNAs in LncRNAs \& disease database were used following the manufacturer's instructions to investigate the association of LncRNAs with radiation response. 


\section{Western blotting analysis}

Protein expression was analyzed by western blotting according to the method described by Meihua Sui et al [16]. Briefly, cells after indicated treatments were harvested by trypsin-EDTA exposure and washed twice with ice-cold PBS before adding into protein extraction buffer. Equal amount of protein was fractionated on 12 $\%$ SDS-PAGE gel and transferred to polyvinylidence difluoride membranes. The membranes were incubated with the indicated primary and secondary antibodies. Proteins were ultimately visualized by enhanced chemiluminescence and autoradiography (ECL; Thermon Scientific, Waltham, MA, UK).

\section{Clonogenic survival assay}

Exponentially growing esophageal squamous cancer cells were seeded into six-wells plate. After $24 \mathrm{~h}$ of incubation, adhesive cells receiving indicated pretreatments were exposed to radiation at $0 \mathrm{~Gy}, 2 \mathrm{~Gy}, 4$ Gy, 6 Gy and 8 Gy with an average dose rate of $100 \mathrm{cGy} /$ $\mathrm{min}$. Then, the cells were cultured for 10 days at $37^{\circ} \mathrm{C}$ in a $5 \% \mathrm{CO}_{2}$ environment to allow colony formation. Only colonies containing $\geq 50$ cells were counted as clonogenic survivors. Untreated cells were chosen as a control.

\section{3-(4, 5-Dimethylthiazol-2-yl)-2,5- diphenyltetrazolium bromide (MTT) assay}

Cell growth was determined by MTT assay. Briefly, adherent cells (5000 cells per well) were evenly plated into 96-wells plate and incubated overnight. Then, cells were exposed to different treatments. After incubation for indicated time, the medium in each well was replaced with fresh culture medium containing $1 \mathrm{mg} /$ $\mathrm{mL}$ of MTT. The plates were incubated for additional 3 $\mathrm{h}$, allowing viable cells to reduce the yellow tetrazolium salt (MTT) into dark blue formazan crystals. Finally, DMSO was added to dissolve the formazan crystals. The absorbance was determined at $562 \mathrm{~nm}$ with a microplate spectrophotometer.

\section{Immunohistochemical staining}

Immunohistochemical staining of WISP1 was performed on paraffin-embedded sections of surgically resected or biopsy specimens of ESCC tissues according to standard procedures [17]. Briefly, sections of 4 um thick were deparaffinized and rehydrated trough a series of graded alcohols. Endogenous peroxidase activity was quenched with $3 \%(\mathrm{v} / \mathrm{v}) \mathrm{H}_{2} \mathrm{O}_{2}$ for 20 minutes. Antigen retrieval was performed with $6.5 \mathrm{mM}$ sodium citrate, $\mathrm{pH}$ 6.0, in a pressure cooker. Non-specific binding was avoided by immersing sections into $3 \%$ bovine serum albumin (BSA) in PBS for $30 \mathrm{~min}$ at room temperature. Then, sections were incubated with antibody against WISP1 and HPR-conjugated secondary antibody, and the color reaction was carried out by exposure to DAB. The sections were counterstained with hematoxylin for $30 \mathrm{~s}$ and dehydrated in alcohol before mounting. The intensity of WISP1 expression was graded as 0 , negative; $1+$, weak cytoplasmic staining; $2+$, strong staining in less than $30 \%$ of tumor cells; $3+$, strong staining in more than $30 \%$ of tumor cells. 0 and $1+$ were defined as WISP1negative; $2+$ and $3+$ as WISP1-positive. The slides were scored by a pathologist and two experienced researchers independently.

\section{Enzyme-linked Immunosorbent Assay (ELISA)}

The concentration of WISP1 in serum of ESCC patients was determined by sandwich ELISA kit (R\&D Systems, Minneapolis, Minnesota, USA) according to the manufacturer's instructions.

\section{Viral transduction of WISP1 shRNA or cDNA}

To establish WISP1-silenced or overexpressed cells, KYSE-150 cells were transduced with lentivirus vectors containing WISP1-targeting shRNA (5'-GCTGTGAGTGCTGTAAGATGT-3') or WISP1 cDNA. Cells transduced with empty vector were used as negative control. WISP1-silenced or overexpressed cells were those clones that survived after treatment with 1 $\mu \mathrm{g} / \mathrm{mL}$ of puromycin and further confirmed by western blotting.

\section{Transfection of BOKAS-targeting siRNA into KYSE-150 cells}

KYSE-150 cells were seeded into 6-wells plate $\left(1 \times 10^{5}\right.$ cells/well $)$ and cultured for $24 \mathrm{~h}$. Adherent cells were incubated with the complex of BOKAS-targeting siRNA and lipofectamin at a final siRNA concentration of $1 \mathrm{nM}, 10 \mathrm{nM}$ or $100 \mathrm{nM} .6 \mathrm{~h}$ later, the transfection medium was replaced with fresh RPMI-1640 medium and cells were cultured for additional $48 \mathrm{~h}$. Cells transfected with empty vector were used as negative control. The mRNA level of BOKAS in KYSE-150 cells after transfection with siRNA or empty vector was detected by qRT-PCR analysis.

\section{Immunofluorescence detection of $\gamma-\mathrm{H} 2 \mathrm{AX}$ expression}

Cells were seeded into 96-wells plate and exposed to $6 \mathrm{~Gy}$ of radiation after adherent growth. 30 minutes 
later, cells were fixed with acetone/methanol (1:1), and permeabilized with $0.1 \%$ Triton-X100 in PBS. Nonspecific binding was blocked with $3 \%(\mathrm{~m} / \mathrm{v})$ BSA in PBS. Then, the cells were incubated with antibody against $\gamma-\mathrm{H} 2 \mathrm{AX}$ for $2 \mathrm{~h}$ in PBS containing $0.1 \%(\mathrm{~m} / \mathrm{v})$ BSA. Indirect immunofluorescence was performed by incubation with Alexa Fluor 488-conjugated secondary antibodies (Zymed; Invitrogen). Cell nucleus was stained with $1 \mu \mathrm{g} / \mathrm{mL}$ of DAPI. Immunofluorescence images were taken using a confocal laser scanning microscope. Data was shown as average intensity of $\gamma-\mathrm{H} 2 \mathrm{AX}$ fluorescence per cell.

\section{High content screening of kinases inhibitors library}

Kinases inhibitors library shown in Supplementary Table S5 was purchased from Selleck (Houston, TX, USA). The compounds were dissolved in DMSO to make $30 \mathrm{mM}$ of stock solution and kept in $-20{ }^{\circ} \mathrm{C}$ until use. The tested cells were seeded into 384 -wells plate $\left(5 \times 10^{3}\right.$ per well) and cultured for adherent growth. After $4 \mathrm{~h}$ of incubation with $30 \mu \mathrm{M}$ of various kinases inhibitors, cells were treated with 6 Gy of radiation, and detection of $\gamma$-H2AX expression was performed $30 \mathrm{~min}$ later as described above.

\section{Xenograft transplantation and therapy}

To develop xenograft tumors, in vitro growing esophageal squamous cancer cells were harvested by exposure to trypsin-EDTA, washed with ice-cold PBS and implanted into the right flanks of female BALB/c nude mice $\left(1.0 \times 10^{5}\right.$ cells in $\left.100 \mu \mathrm{PBS}\right)$. When xenograft tumors had reached a mean diameter of around $0.5 \mathrm{~cm}$, mice were randomly assigned into different groups (five mice in each group). Tumors were treated with 12 Gy of radiation in three fractions every four days, $4 \mu \mathrm{g} / \mathrm{mL}$ of anti-WISP1 antibody or $2 \mu \mathrm{g} / \mathrm{mL}$ of recombinant WISP 1 protein daily for 12 consecutive days, alone or in their combinations. Each animal was earmarked and followed individually throughout the experiments. Tumor volume $\left(\mathrm{mm}^{3}\right)$ was calculated using the following formula: $\mathrm{V}\left(\mathrm{mm}^{3}\right)=\mathrm{A}(\mathrm{mm}) \times \mathrm{B}(\mathrm{mm})^{2} / 2$, where $\mathrm{A}$ and $\mathrm{B}$ were the longest and widest diameter of tumor, respectively, and measured every two days by a caliper.

\section{Statistics analysis}

All of the experiments in our study were independently performed in triplicate and data were presented as means \pm SD. Statistical analyses were performed with SPSS software 16.0 (SPSS). Univariate survival analyses were performed with Kaplan-Meier method and log-rank tests. The other statistical analyses were performed with Student's t-test. Differences were considered statistically significant at a level of $p<0.05$.

\section{ACKNOWLEDGEMENTS}

The authors thank Wei Yu and Qiang Hou for their technical assistance. This work was financially supported by National Natural Science Foundation of China (No. 81402529), Zhejiang Provincial Foundation for Natural Sciences (No. LY14H160005) and Hangzhou Science and Technology Planning Project of Health \& Medicine (No. 2012ZD002).

\section{Conflict of interest}

The authors declare that they have no potential or actual conflicts of interest.

\section{REFERENCES}

1. Enzinger PC and Mayer RJ. Medical progress - Esophageal cancer. New ENJL J MED. 2003;349:2241-2252.

2. Cooper JS, Guo MD, Herskovic A, Macdonald JS, Martenson JA, Al-Sarraf M, Byhardt R, Russell AH, Beitler JJ, Spencer S, Asbell SO, Graham MV and Leichman LL. Chemoradiotherapy of locally advanced esophageal cancer - Long-term follow-up of a prospective randomized trial (RTOG 85-01). Jama-J Am Med Assoc. 1999;281:16231627.

3. Minsky BD, Pajak TF, Ginsberg RJ, Pisansky TM, Martenson J, Komaki R, Okawara G, Rosenthal SA and Kelsen DP. INT 0123 (radiation therapy oncology group 94-05) phase III trial of combined-modality therapy for esophageal cancer: High-dose versus standard-dose radiation therapy. J Clin Oncol. 2002;20:1167-1174.

4. Bussink J, van der Kogel AJ and Kaanders J. Activation of the PI3-K/AKT pathway and implications for radioresistance mechanisms in head and neck cancer. Lancet Oncol. 2008;9:288-296.

5. De Bacco F, Luraghi P, Medico E, Reato G, Girolami F, Perera T, Gabriele P, Comoglio PM and Boccaccio C. Induction of MET by Ionizing Radiation and Its Role in Radioresistance and Invasive Growth of Cancer. J Natl Cancer I. 2011;103:645-661.

6. Uzawa K, Ishigami T, Fushimi K, Kawata T, Shinozuka K, Kasamatsu A, Sakamoto Y, Ogawara K, Shiiba M, Bukawa $\mathrm{H}$, Ito $\mathrm{H}$ and Tanzawa $\mathrm{H}$. Targeting fibroblast growth factor receptor 3 enhances radiosensitivity in human squamous cancer cells. Oncogene. 2011;30:4447-4452.

7. Kim Y, Kim KH, Lee J, Lee YA, Kim M, Lee SJ, Park $\mathrm{K}$, Yang H, Jin J, Joo KM and Nam DH. Wnt activation is implicated in glioblastoma radioresistance. Lab Invest. 2012;92:466-473. 
8. Chen MS, Woodward WA, Behbod F, Peddibhotla S, Alfaro MP, Buchholz TA and Rosen JM. Wnt/beta-catenin mediates radiation resistance of $\mathrm{Sca}(+)$ progenitors in an immortalized mammary gland cell line. J Cell Sci. 2007;120:468-477.

9. Chang HW, Roh JL, Jeong EJ, Lee SW, Kim SW, Choi SH, Park SK and Kim SY. Wnt signaling controls radiosensitivity via cyclooxygenase-2-mediated $\mathrm{Ku}$ expression in head and neck cancer. Int $\mathrm{J}$ Cancer. 2008;122:100-107.

10. Pennica D, Swanson TA, Welsh JW, Roy MA, Lawrence DA, Lee J, Brush J, Taneyhill LA, Deuel B, Lew M, Watanabe C, Cohen RL, Melhem MF, Finley GG, Quirke P, Goddard AD, et al. WISP genes are members of the connective tissue growth factor family that are up-regulated in wnt-1-transformed cells and aberrantly expressed in human colon tumors. P Natl Acad Sci USA. 1998;95:14717-14722.

11. Berschneider B and Konigshoff M. WNT1 inducible signaling pathway protein 1 (WISP1): A novel mediator linking development and disease. Int J Biochem Cell B. 2011;43:306-309.

12. Xu LF, Corcoran RB, Welsh JW, Pennica D and Levine AJ. WISP-1 is a Wnt-1-and beta-catenin-responsive oncogene. Genes Dev. 2000;14:585-595.

13. Su F, Overholtzer M, Besser D and Levine AJ. WISP-1 attenuates p53-mediated apoptosis in response to DNA damage trough activation of the Akt kinase. Genes Dev. 2002;16:46-57.

14. Nagai $Y$, Watanabe M, Ishikawa S, Karashima R, Kurashige J, Iwagami S, Iwatsuki M, Baba Y, Imamura Y, Hayashi N and Baba H. Clinical Significance of Wnt-induced Secreted Protein-1 (WISP-1/CCN4) in Esophageal Squamous Cell Carcinoma. Anticancer Res. 2011;31:991-997.

15. Jing Z, Gong L, Xie CY, Zhang L, Su HF, Deng X and Wu SX. Reverse resistance to radiation in KYSE-150R esophageal carcinoma cell after epidermal growth factor receptor signal pathway inhibition by cetuximab. Radiother Oncol. 2009;93:468-473.

16. Sui M, Huang Y, Park BH, Davidson NE and Fan W. Estrogen receptor alpha mediates breast cancer cell resistance to paclitaxel through inhibition of apoptotic cell death. Cancer Res. 2007;67:5337-5344.

17. Konigshoff M, Kramer M, Balsara N, Wilhelm J, Amarie OV, Jahn A, Rose F, Fink L, Seeger W, Schaefer L, Gunther A and Eickelberg O. WNT1-inducible signaling protein-1 mediates pulmonary fibrosis in mice and is upregulated in humans with idiopathic pulmonary fibrosis. J Clin Invest. 2009;119:772-787.

18. Nishimoto Y, Nakagawa S, Hirose T, Okano HJ, Takao M, Shibata S, Suyama S, Kuwako K, Imai T, Murayama S, Suzuki N and Okano H. The long non-coding RNA nuclearenriched abundant transcript 1_2 induces paraspeckle formation in the motor neuron during the early phase of amyotrophic lateral sclerosis. Mol Brain. 2013; 6:31.
19. Venkatesan B, Prabhu SD, Venkatachalam K, Mummidi S, Valente AJ, Clark RA, Delafontaine P and Chandrasekar B. WNT1-inducible signaling pathway protein-1 activates diverse cell survival pathways and blocks doxorubicininduced cardiomyocyte death. Cell Signal. 2010;22:809820.

20. Clevers H. Wnt/beta-catenin signaling in development and disease. Cell. 2006;127:469-480.

21. Ke C, Tran K, Chen Y, Di Donato AT, Yu L, Hu Y, Linskey ME, Wang PH, Limoli CL and Zhou YH. Linking differential radiation responses to glioma heterogeneity. Oncotarget. 2014;5:1657-1665.

22. Lin HY, Hung SK, Lee MS, Chiou WY, Huang TT, Tseng CE, Shih LY, Lin RI, Lin JM, Lai YH, Chang CB, Hsu FC, Chen LC, Tsai SJ, Su YC, Li SC, et al. DNA methylome analysis identifies epigenetic silencing of FHIT as a determining factor for radiosensitivity in oral cancer: an outcome-predicting and treatment-implicating study. Oncotarget. 2014.

23. Lv P, Wang Y, Ma J, Wang Z, Li JL, Hong CS, Zhuang Z and Zeng YX. Inhibition of protein phosphatase $2 \mathrm{~A}$ with a small molecule LB100 radiosensitizes nasopharyngeal carcinoma xenografts by inducing mitotic catastrophe and blocking DNA damage repair. Oncotarget. 2014;5:75127524.

24. Meng J, Li P, Zhang Q, Yang Z and Fu S. A radiosensitivity gene signature in predicting glioma prognostic via EMT pathway. Oncotarget. 2014;5:4683-4693.

25. Qian D, Zhang B, Zeng XL, Le Blanc JM, Guo YH, Xue C, Jiang C, Wang HH, Zhao TS, Meng MB, Zhao LJ, Hao JH, Wang P, Xie D, Lu B and Yuan ZY. Inhibition of human positive cofactor 4 radiosensitizes human esophageal squmaous cell carcinoma cells by suppressing XLF-mediated nonhomologous end joining. Cell Death Dis. 2014;5.

26. Zhang C, Yang X, Zhang Q, Guo Q, He J, Qin Q, Zhu HC, Liu J, Zhan LL, Lu J, Liu ZM, Xu LP, Ma JX, Dai SB, Cheng HY and Sun XC. STAT3 inhibitor NSC74859 radiosensitizes esophageal cancer via the downregulation of HIF-1 alpha. Tumor Biol. 2014;35:9793-9799.

27. Zhu HG, Yang X, Liu J, Ge YY, Qin Q, Lu J, Zhan LL, Liu ZM, Zhang H, Chen XC, Zhang C, Xu LP, Cheng HY and Sun XC. Melittin radiosensitizes esophageal squamous cell carcinoma with induction of apoptosis in vitro and in vivo. Tumor Biol. 2014;35:8699-8705.

28. Qin Q, Cheng HY, Lu J, Zhan LL, Zheng JC, Cai J, Yang X, Xu LP, Zhu HC, Zhang C, Liu J, Ma JX, Zhang XZ, Dai SB and Sun XC. Small-molecule survivin inhibitor YM155 enhances radiosensitization in esophageal squamous cell carcinoma by the abrogation of G(2) checkpoint and suppression of homologous recombination repair. J Hematol Oncol. 2014;7.

29. Qin Q, Zuo Y, Yang X, Lu J, Zhan LL, Xu LP, Zhang C, Zhu HC, Liu J, Liu ZM, Tao GZ, Dai SB, Zhang XZ, Ma JX, Cai J and Sun XC. Smac mimetic compound LCL161 
sensitizes esophageal carcinoma cells to radiotherapy by inhibiting the expression of inhibitor of apoptosis protein. Tumor Biol. 2014;35:2565-2574.

30. Luo JD, Zhou XF, Ge X, Liu PF, Cao JP, Lu XJ, Ling Y and Zhang SY. Upregulation of Ying Yang 1 (YY1) suppresses esophageal squamous cell carcinoma development through heme oxygenase-1. Cancer Sci. 2013; 104:1544-1551.

31. Yang CR, Wang YD, Zhang FL, Sun GG, Li CL, Jing SW, Liu Q and Cheng YJ. Inhibiting UHRF1 expression enhances radiosensitivity in human esophageal squamous cell carcinoma. Mol Biol Rep. 2013;40:5225-5235.

32. Wang GY, Liu LY, Sharma S, Liu H, Yang WF, Sun XN and Dong QH. Bmi-1 confers adaptive radioresistance to KYSE-150R esophageal carcinoma cells. Biochem Bioph Res Co. 2012;425:309-314.

33. Jun JI and Lau LF. Taking aim at the extracellular matrix: CCN proteins as emerging therapeutic targets. Nat Rev Drug Discov. 2011;10:945-963.

34. Lundholm L, Haag P, Zong D, Juntti T, Mork B, Lewensohn $\mathrm{R}$ and Viktorsson $\mathrm{K}$. Resistance to DNAdamaging treatment in non-small cell lung cancer tumorinitiating cells involves reduced DNA-PK/ATM activation and diminished cell cycle arrest. Cell Death Dis. 2013;4.

35. Sugrue T, Brown JAL, Lowndes NF and Ceredig R. Multiple Facets of the DNA Damage Response Contribute to the Radioresistance of Mouse Mesenchymal Stromal Cell Lines. Stem Cells. 2013;31:137-145.

36. Nagelkerke A, Bussink J, van der Kogel AJ, Sweep F and Span PN. The PERK/ATF4/LAMP3-arm of the unfolded protein response affects radioresistance by interfering with the DNA damage response. Radiother Oncol. 2013;108:415-421.

37. Carruthers R, Ahmed S and Chalmers AJ. Inhibition of DNA damage response abrogates glioblastoma cancer stem cell radioresistance. Neuro-Oncol. 2014;16.

38. Zhang P, Wei Y, Wang L, Debeb BG, Yuan Y, Zhang JS, Yuan JS, Wang M, Chen DH, Sun YT, Woodward WA, Liu YQ, Dean DC, Liang H, Hu Y, Ang KK, et al. ATMmediated stabilization of ZEB1 promotes DNA damage response and radioresistance through $\mathrm{CH}$ K1. Nat Cell Biol. 2014; $16: 864-875$.

39. Santivasi WL and Xia F. Ionizing Radiation-Induced DNA Damage, Response, and Repair. Antioxid Redox Sign. 2014;21:251-259.

40. Hosoya N and Miyagawa K. Targeting DNA damage response in cancer therapy. Cancer Sci. 2014; 105:370-388.

41. Schutze C and Krause M. Radioresistance of K-ras-mutated human tumor cells is mediated through EGFR-dependent activation of PI3K-AKT pathway. Strahlenther Onkol. 2006;182:252-253.

42. Chang L, Graham PH, Hao JL, Jie N, Bucci J, Cozzi PJ, Kearsley JH and Li Y. Preclinical studies of the combination of dual PI3K/Akt/mTOR inhibitors with radiotherapy to overcome radioresistant prostate cancer. Int
J Mol Med. 2014;34:S50-S50.

43. Chang L, Graham PH, Hao J, Ni J, Bucci J, Cozzi PJ, Kearsley JH and Li Y. PI3K/Akt/mTOR pathway inhibitors enhance radiosensitivity in radioresistant prostate cancer cells through inducing apoptosis, reducing autophagy, suppressing NHEJ and HR repair pathways. Cell Death Dis. $2014 ; 5$.

44. Soon LL, Yie TA, Shvarts A, Levine AJ, Su F and TchouWong KM. Overexpression of WISP-1 down-regulated motility and invasion of lung cancer cells through inhibition of Rac activation. J Biol Chem. 2003;278:11465-11470.

45. Tang QL, Jiang XF, Li HG, Lin ZQ, Zhou XD, Luo X, Liu L and Chen GB. Expression and prognostic value of WISP-1 in patients with endometrial endometrioid adenocarcinoma. J Obstet Gynaecol Res. 2011;37:606-612.

46. Davies SR, Watkins G, Mansel RE and Jiang WG. Differential expression and prognostic implications of the CCN family members WISP-1, WISP-2, and WISP-3 in human breast cancer. Ann Surg Oncol. 2007;14:1909-1918.

47. Davies SR, Davies ML, Sanders A, Parr C, Torkington J and Jiang WG. Differential expression of the CCN family member WISP-1, WISP-2 and WISP-3 in human colorectal cancer and the prognostic implications. Int $\mathrm{J}$ Oncol. 2010;36:1129-1136.

48. Ono M, Inkson CA, Sonn R, Kilts TM, de Castro LF, Maeda A, Fisher LW, Robey PG, Berendsen AD, Li L, McCartneyFrancis N, Brown AC, Crawford NPS, Molinolo A, Jain A, Fedarko NS, et al. WISP1/CCN4: A Potential Target for Inhibiting Prostate Cancer Growth and Spread to Bone. Plos One. 2013;8.

49. Chuang JY, Chang AC, Chiang IP, Tsai MH and Tang CH. Apoptosis Signal-Regulating Kinase 1 Is Involved in WISP1-Promoted Cell Motility in Human Oral Squamous Cell Carcinoma Cells. Plos One. 2013;8.

50. Chang AC. WISP-1 increases cell migration and ICAM-1 expression in human oral squamous cell carcinomas. Cancer Res. 2013;73.

51. Wilusz JE, Sunwoo H and Spector DL. Long noncoding RNAs: functional surprises from the RNA world. Gene Dev. 2009;23:1494-1504.

52. Kim ED and Sung S. Long noncoding RNA: unveiling hidden layer of gene regulatory networks. Trends Plant Sci. 2012;17:16-21.

53. Yoon JH, Abdelmohsen $\mathrm{K}$ and Gorospe $\mathrm{M}$. Posttranscriptional Gene Regulation by Long Noncoding RNA. J Mol Biol. 2013; 425(19):3723-3730.

54. Ozgur E, Mert U, Isin M, Okutan M, Dalay N and Gezer U. Differential expression of long non-coding RNAs during genotoxic stress-induced apoptosis in HeLa and MCF-7 cells. Clin Exp Med. 2013;13:119-126.

55. Chaudhry MA. Expression Pattern of Small Nucleolar RNA Host Genes and Long Non-Coding RNA in X-rays-Treated Lymphoblastoid Cells. Int J Mol Sci. 2013;14:9099-9110.

56. Wang QR, Fan HN, Liu Y, Yin ZX, Cai HB, Liu J, 
Wang ZY, Shao M, Sun XG, Diao JX, Liu YL, Tong L and Fan Q. Curcumin enhances the radiosensitivity in nasopharyngeal carcinoma cells involving the reversal of differentially expressed long non-coding RNAs. Int $\mathbf{J}$ Oncol. 2014;44:858-864.

57. Chaudhry MA. Small Nucleolar RNA Host Genes and Long Non-Coding RNA Responses in Directly Irradiated and Bystander Cells. Cancer Biothe Radio. 2014;29:135-141.

58. Zhang H, Gao SP and De Geyter C. A natural antisense transcript, BOKAS, regulates the pro-apoptotic activity of human Bok. Int J Oncol. 2009;34:1135-1138.

59. Mizushima T, Nakagawa H, Kamberov YG, Wilder EL, Klein PS and Rustgi AK. Wnt-1 but not epidermal growth factor induces beta-catenin/T-cell factor-dependent transcription in esophageal cancer cells. Cancer Res. 2002;62:277-282. 